\title{
UJIAN SEKOLAH SEBAGAI UPAYA PEMETAAN MUTU SEKOLAH DASAR
}

\section{SCHOOL EXAM AS AN EFFORT FOR PRIMARY SCHOOL QUALITY MAPPING}

\author{
Rogers Pakpahan \\ Pusat Penilaian Pendidikan, Balitbang, Kemedikbud \\ Jalan Gunung Sahari Raya No 4 Jakarta \\ e-mail: ropakpakro@yahoo.com
}

Naskah diterima tanggal: 22/02/2015, Direvisi akhir tanggal: 31/04/2015, disetujui tanggal: 06/08/2015

\begin{abstract}
This study aims to examine the role of school exams for mapping the quality of primary schools in the compulsory education. The method used in this study are a descriptive analysis of the implementation document school exams and the results of the monitoring and data processing descriptive analysis. The results showed that: 1) assessment by educators in the context of the learning process can not be used as the quality mapping material of elementary school because the tests used by educators not standard and not the same quality; 2) School Exam results can be used as the quality mapping material of elementary school because the exam using standard tests and are relatively similar between the educational unit; 3) the results of the mapping quality based on school exams can be used as a basis for improving the quality of education in primary school through policy intervention by stakeholders (each school, district/cities education offices, and provinces). The conclusion of study of school examinations can be used as a basis for mapping the quality of primary schools and based on the quality of these schools can be used as a basis for fulfilling the needs school facilities to improve the quality of education in the implementation of compulsory basic education.
\end{abstract}

Keywords: educational assessment, school mapping, school exam, policy intervention, quality of education

Abstrak: Penulisan ini bertujuan untuk mengkaji peran ujian sekolah untuk pemetaan mutu sekolah dasar dalam rangka wajib belajar pendidikan dasar. Metode yang digunakan dalam kajian ini yaitu analisis diskriptif pada dokumen penyelenggaraan dan hasil pemantauan pelaksanaan ujian sekolah sedang pengolahan data dilakukan dengan analisis deskriptif. Hasil kajian menunjukkan bahwa: 1) penilaian oleh pendidik dalam rangka proses pembelajaran tidak dapat dijadikan sebagai bahan pemetaan mutu sekolah dasar karena tes yang digunakan pendidik tidak baku serta tidak sama kualitasnya; 2) hasil ujian sekolah dapat dijadikan sebagai bahan pemetaan mutu sekolah dasar karena dalam ujian menggunakan tes baku dan relatif sama antar satuan pendidikan; 3) hasil pemetaan mutu berdasarkan ujian sekolah dapat dijadikan sebagai dasar untuk meningkatkan mutu pendidikan di sekolah dasar melalui intervensi kebijakan oleh pemangku kepentingan (satuan pendidikan, dinas pendidikan kabupaten/kota, dan provinsi). Kajian ini menyimpulkan pelaksanaan ujian sekolah dapat dijadikan sebagai dasar pemetaan mutu sekolah dasar dan berdasarkan mutu sekolah tersebut dapat dijadikan sebagai dasar untuk pemenuhan kebutuhan/fasilitas sekolah untuk meningkatkan mutu pendidikan dalam rangka pelaksanaan wajar dikdas.

Kata kunci: penilaian pendidikan, pemetaan sekolah, ujian sekolah, intervensi kebijakan, kualitas pendidikan SD 


\section{PENDAHULUAN}

Pendidikan merupakan upaya sadar yang dilakukan suatu negara untuk meningkatkan mutu sumber daya manusia di negara tersebut. Pendidikan merupakan sarana intervensi kehidupan dan agen pembaharu untuk memperluas akses dan mobilitas sosial dalam masyarakat secara vertikal dan horizontal. Pendidikan yang diperoleh warga negara merupakan upaya pengembangan sumber daya manusia yang dibutuhkan untuk memasuki abad 21 sebagai era globalisasi dan untuk menghadapi dinamika perubahan kehidupan global. Pendidikan memberikan kesempatan pada warga negara untuk mengembangkan dan mengoptimalkan segenap potensi yang dimilikinya agar dapat memberikan sumbangan bahkan mengontrol perkembangan kehidupan masa depannya.

Dalam sistem pendidikan nasional, Sekolah Dasar (SD) dan Sekolah Menengah Pertama (SMP) merupakan satu kesatuan program pendidikan dasar yang proses pendidikannya diwujudkan secara berkelanjutan dalam satu jenjang pendidikan. Dengan demikian, peserta didik SD otomatis masuk ke SMP tanpa harus mengikuti seleksi atau ujian sekolah. Dalam praktiknya hal tersebut sulit diwujudkan karena selama ini proses pendidikan di SD dan SMP terpisah satu sama lain. Dewasa ini, Pemerintah menetapkan kebijakan pogram Satu Atap (satap) yang menyatukan SD dan SMP terutama di daerah terpencil. Proses pembelajaran tetap berlangsung secara mandiri (SD dan SMP) bukan merupakan kelanjutan walaupun di dalam gedung yang sama. Sesuai uraian tersebut tampak bahwa pelaksanaan ujian akhir pada setiap satuan pendidikan mutlak dilakukan, yaitu SD di kelas enam dan SMP di kelas sembilan. Ujian akhir dilakukan pada akhir masa pembelajaran yang bertujuan untuk memeroleh gambaran pencapaian kompetensi pada satuan pendidikan. Ujian akhir di SD disebut dengan Ujian Sekolah sebagai upaya kerja keras dan semangat bersama menuju pencapaian pendidikan nasional yang bermutu di tingkat regional dan internasional (Tola, 2007).
Proses pendidikan terjadi atau terbentuk melalui kerja sama antara tenaga pendidik (guru) dan peserta didik serta materi atau topik pengetahuan sebagai media untuk mencapai suatu kompetensi yang merupakan kemampuan dan kecakapan yang terukur setelah peserta didik mengikuti proses pembelajaran secara keseluruhan meliputi kemampuan akademik, sikap, dan keterampilan. Proses pendidikan terjadi atau dilakukan di ruang kelas atau di luar kelas yang kita sebut pembelajaran. Kegiatan pembelajaran bertujuan untuk mencapai kompetensi yang telah ditetapkan dalam kurikulum di tingkat satuan pendidikan. Untuk mencapai kompetensi tersebut ada tiga komponen yang saling berkaitan yaitu tujuan pembelajaran, pengalaman belajar, dan hasil belajar. Tujuan pembelajaran merupakan tujuan yang hendak dicapai dalam proses pembelajaran yang dituangkan dalam rencana program pembelajaran (RPP). Pengalaman belajar atau proses pembelajaran merupakan proses pengalihan (transfer) pengetahuan, keterampilan, dan sikap oleh pendidik kepada peserta didik. Untuk memeroleh informasi pencapaian kompetensi atau hasil belajar peserta didik dari pembelajaran, dilakukan penilaian untuk memeroleh pencapaian kompetensi yang ditetapkan. Ketiga kegiatan dimaksud berlangsung secara berkelanjutan (siklus) mulai dari penyusunan tujuan pembelajaran yang dilanjukan dengan proses pembelajaran serta diakhiri penilaian. Hasil penilaian digunakan untuk mengecek apakah proses pembelajaran berlangsung dengan baik serta tujuan pembelajaran tercapai atau tidak. Bila hasil penilaian rendah atau tujuan pembelajaran tidak tercapai maka hasil tersebut digunakan pendidik sebagai umpan balik (pendidik dan peserta didik) untuk perbaikan pembelajaran lebih lanjut.

Penilaian dalam proses pembelajaran di kelas merupakan bagian integral dari tugas para pendidik dalam mencerdaskan peserta didik. Penilaian dilakukan untuk mengukur pencapaian kompetensi dalam kurikulum dan untuk memberikan gambaran tentang pencapaian tujuan 
pembelajaran (Purwati, 2009). Dalam pengukuran pencapaian kompetensi, para pendidik sejak awal sudah menentukan apa atau kompetensi yang harus dicapai peserta didik. Dengan cara tersebut, pendidik dapat merumuskan instrumen penilaian yang diperlukan. Pendidik dalam penilaian menerapkan berbagai bentuk penilaian yang diharapkan dapat membangkitkan semangat belajar dan peserta didik lebih gairah atau tertantang untuk mempelajari atau mencapai kompetensi yang telah ditetapkan dalam kurikulum. Dalam penilaian diperlukan instrumen penilaian yang dapat memotivasi peserta didik untuk belajar lebih lanjut. Motivasi belajar ini sangat penting untuk meningkatkan prestasi peserta didik. Instrumen penilaian yang digunakan pendidik merupakan tes yang disusun dan dikembangkan oleh pendidik, yang menurut Basuki dan Hariyanto (2014) perlu diperhatikan beberapa aspek agar tes tersebut secara konstruksi lebih baik. Secara tidak langsung Basuki dan Hariyanto meragukan kualitas tes buatan guru sehingga perlu upaya pengembangan agar tes tersebut lebih berkualitas paling tidak dari segi konstruksi. Secara umum, prosedur pengembangan tes buatan guru dilakukan pada saat akan melakukan ujian sehingga bentuk dan kualitasnya beragam. Seyogyanya tes buatan guru tersebut haruslah ditelaah sampai menjadi tes yang standar dan hasilnya dapat digunakan untuk memetakan hasil pembelajaran. Untuk memeroleh instrumen standar hendaknya dilakukan analisis butir soal dengan memperhatikan kaidah-kaidah pengukuran yang ada (Sudaryono, 2012). Kaidah pengukuran meliputi penyusunan kisi-kisi, penyusunan soal, telaah, revisi, penggandaan serta pelaksanaan ujian. Melalui prosedur tersebut diperoleh instrumen standar yaitu tes yang memiliki karateristik (validitas butir) dan reliabilitas sehingga dipercaya mengukur apa yang akan diukur. Penggunaan instrumen baku/ standar di seluruh satuan pendidikan (SD) diharapkan menghasilkan data/informasi yang relatif sama dan data tersebut digunakan sebagai dasar pemetaan mutu satuan pen- didikan. Melalui pemetaan tersebut dilakukan pengkajian kelemahan dan kelebihan mutu suatu sekolah sehingga bisa dilakukan intervensi kebijakan. Proses demikian diharapkan dapat meningkatkan mutu pendidikan dalam rangka pelaksanaan wajib belajar Dikdas. Untuk itu, diperlukan instrumen yang setara atau sama sehingga hasil penilaian dapat dibandingkan antarsatuan pendidikan di Indonesia.

Dalam kajian ini, yang menjadi permasalahan adalah: 1) apakah penilaian pendidik dalam proses pembelajaran (ujian) dapat digunakan untuk pemetaan mutu pendidikan di sekolah dasar? 2) apakah Ujian Sekolah dapat digunakan sebagai dasar pemetaan sekolah dasar? dan 3) apakah melalui pemetaan SD dapat meningkatkan mutu SD dalam rangka pelaksanaan wajib belajar Dikdas?

Tujuan kajian ini dimaksudkan untuk: 1) mengkaji peran penilaian pendidik dalam proses pembelajaran di satuan pendidikan dapat digunakan untuk pemetaan mutu pendidikan di Sekolah Dasar; 2) mendapatkan gambaran penyelenggaraan ujian sekolah sebagai dasar pemetaan Sekolah Dasar; dan 3) mengkaji hasil pemetaan sekolah dasar dijadikan sebagai bahan intervensi kebijakan untuk meningkatkan mutu sekolah dasar dalam pelaksanaan wajib belajar pendidikan dasar.

\section{KAJIAN LITERATUR}

\section{Sistem Pendidikan di Indonesia}

Dalam sistem pendidikan nasional, pendidikan dikelompokkan menjadi pendidikan formal, pendidikan nonformal, dan pendidikan informal. Pendidikan formal lebih dikenal dengan pendidikan jalur sekolah dan pendidikan nonformal dengan pendidikan luar sekolah serta pendidikan informal dengan pendidikan dalam keluarga. Lebih lanjut, pendidikan formal terdiri atas pendidikan dasar, pendidikan menengah, dan pendidikan tinggi. Pendidikan nonformal terdiri atas pendidikan kecakapan hidup, pendidikan anak usia dini, pendidikan kepemudaan, pendidikan keaksaraan, pendidikan keterampilan dan pelatihan kerja, dan pendidikan 
kesetaraan. Penilaian dalam sistem pendidikan nasional terdiri atas penilaian oleh pendidik (penilaian berbasis kelas), penilaian oleh satuan pendidikan (ujian sekolah), dan penilaian oleh pemerintah (ujian nasional).

Pendidikan nasional berfungsi sebagai alat utama untuk mengembangkan kemampuan serta meningkatkan mutu kehidupan dan martabat bangsa Indonesia. Pendidikan pada hakikatnya merupakan investasi dalam peningkatan kualitas sumber daya manusia. Pendidikan diyakini dapat meningkatkan dan mempertinggi kualitas tenaga kerja, sehingga memungkinkan tersedianya angkatan kerja yang terampil, handal, dan sesuai dengan tuntutan pembangunan serta peningkatan produktivitas nasional. Pendidikan merupakan upaya untuk mengembangkan kecerdasan kognitif dan kecerdasan emosional sebagai modal dasar untuk mengerjakan tugas yang diemban serta untuk menghadapi dinamika kehidupan global.

Upaya pengembangan kecerdasan kognitif maupun emosional diwujudkan Pemerintah melalui penyelenggaraan satu sistem pengajaran nasional, yang diwujudkan dalam penetapan Undang-Undang Pendidikan Nasional yang telah berulang kali direvisi dan diganti, penyusunan kurikulum, Standar Pendidikan Nasional, serta pelaksanaan wajib belajar yang memberikan kesempatan belajar seluas-luasnya kepada masyarakat dengan pendidikan yang berkualitas. Upaya tersebut dilakukan dalam rangka meningkatkan mutu pendidikan nasional sesuai dengan tuntutan nasional dan global (Somantrie, 2009). Mutu merupakan ukuran baik buruk suatu benda, taraf atau derajat kepandaian atau kecerdasan dalam ilmu pengetahuan (Pusat Bahasa, 2005). Lebih lanjut menurut Somantrie, mutu pendidikan adalah konsep yang kompleks karena mutu pendidikan memiliki banyak dimensi, menyangkut serangkaian proses dan berbagai indikator yang harus dijelaskan secara rinci. Mutu pendidikan mencerminkan kualitas proses dan hasilnya sehingga satuan pendidikan perlu diberikan kewenangan untuk mengatur dirinya dalam rangka peningkatan mutu pendidikan
(Cahyana, 2010). Dalam kajian ini, mutu pendidikan dilihat dari dimensi capaian peserta didik dalam mengikuti Ujian Sekolah yang tergambarkan dalam informasi statistik dan daya serap peserta didik pada Ujian Sekolah. Penulis, menyakini masih ada dimensi lain yang dapat menunjukkan mutu pendidikan di SD namun melalui dua dimensi tersebut dapat dilakukan kajian untuk intervensi kebijakan dalam rangka peningkatan mutu pendidikan di SD.

\section{Program Wajib Belajar}

Program pendidikan wajib belajar (Wajar) di Indonesia telah dirintis sejak tahun 1950, yang menetapkan setiap anak usia 8-14 tahun dikenakan pendidikan Wajar, namun tidak dapat berjalan sebagaimana diharapkan karena adanya pergolakan politik secara terus-menerus yang dikenal dengan masa mempertahankan kemerdekaan Indonesia. Program tersebut dimaksudkan sebagai upaya Pemerintah memberi kesempatan belajar seluas-luasnya kepada setiap warga negara (masyarakat) untuk meningkatkan kualitas sumber daya manusia Indonesia melalui pendidikan. Pendidikan wajib belajar mendapat perhatian pemerintah Orde Baru sejalan dengan gerak pembangunan yang dilaksanakan Pemerintah. Pendidikan wajib belajar sebagai suatu gerakan secara nasional dan sekaligus sebagai bagian tak terpisahkan dari pembangunan nasional. Gerakan wajib belajar merupakan upaya Pemerintah untuk menyediakan sarana dan prasarana belajar peserta didik. Untuk itu, pemerintah melaksanakan pendidikan wajib belajar sembilan tahun (Wajar Dikdas), yang berfungsi untuk meningkatkan kualitas sumber daya manusia hingga tingkat pendidikan penduduk minimal tamatan SMP. Sekarang ini, pemerintah sedang mempersiapkan program Wajar 12 tahun yaitu wajib belajar hingga SMA atau bentuk lain yang sederajat.

\section{Penilaian Pendidikan}

Dalam rangka menjamin kualitas pendidikan nasional, Pemerintah telah menetapkan Standar 
Nasional Pendidikan yang terdiri atas standar isi, standar proses, standar kompetensi lulusan, standar pendidik dan tenaga kependidikan, standar sarana dan prasarana, standar pengeIolaan, standar pembiayaan, dan standar penilaian. Dalam standar tersebut dijabarkan tentang kriteria dan standar yang harus dipenuhi satuan pendidikan dalam pelaksanaan pembelajaran di sekolah. Standar atau kriteria tersebut merupakan acuan para pendidik dan sekolah dalam penyelenggaraan pendidikan. Pemenuhan standar atau kriteria tersebut memudahkan proses pembelajaran karena sudah tersedia fasilitas yang diperlukan satuan pendidikan sesuai standar nasional pendidikan. Ketersediaan fasilitas tersebut akan sangat membantu pendidik dalam proses pembelajaran untuk mencapai kompetensi dalam standar isi serta diharapkan akan menghasilkan lulusan yang lebih bermutu.

Standar Pendidikan Nasional dijadikan sebagai acuan atau referensi pelaksanaan pendidikan di setiap satuan pendidikan. Dalam perencanaan pembelajaran diperlukan standar isi sebagai acuan bagi pendidik dalam penyusunan rencana pembelajaran suatu topik atau kompetensi yang harus dicapai oleh setiap peserta didik sesuai kurikulum serta standar proses sebagai acuan dalam pembelajaran berkualitas membutuhkan sarana dan prasarana yang memadai. Untuk memeroleh informasi pencapaian kompetensi yang sudah diajarkan para pendidik berpedoman pada standar kompetensi lulusan dan standar penilaian. Dalam standar tersebut ditentukan bentuk-bentuk penilaian dan kompetensi yang harus dicapai peserta didik. Pemenuhan standar-standar yang ditetapkan dalam standar nasional pendidikan, diharapkan menghasilkan pendidikan bermutu sebab sudah ditentukan kriteria yag harus dibutuhkan dalam pelaksanaan pendidikan di sekolah dasar. Peranan pemenuhan standar dalam meningkatkan prestasi peserta didik meningkat (Raharjo, 2014) walaupun tidak secara signifikan dan standar tersebut secara signifikan meningkatkan prestasi untuk menghadapi Ujian Nasional di SMA yaitu standar pendidik dan tenaga kependidikan.

Penilaian pendidikan digunakan untuk memprediksi kompetensi dan menentukan apakah tujuan pembelajaran peserta didik telah tercapai selama proses pembelajaran di satuan pendidikan. Penilaian pendidikan dilakukan secara berkesinambungan mulai dari materi atau kompetensi awal tiap jenjang kelas atau semester hingga kompetensi akhir pada satuan pendidikan, dilakukan secara internal dan eksternal. Penilaian internal adalah penilaian yang dilakukan oleh pendidik pada satuan pendidikan yang pada dasarnya digunakan untuk menilai pencapaian hasil belajar peserta didik sebagai dasar untuk memperbaiki proses pembelajaran, serta bahan penyusunan laporan kemajuan hasil belajar peserta didik. Penilaian eksternal adalah penilaian yang dilakukan oleh pihak luar dari satuan pendidikan yang berupa penilaian akhir atau sejenisnya.

Penilaian (ujian) akhir merupakan penilaian pencapaian kompetensi peserta didik selama mengikuti proses belajar di tingkat satuan pendidikan yang didasarkan pada capaian peserta didik dalam proses pembelajaran di satuan pendidikan. Capaian kompetensi merupakan catatan pendidik tentang perilaku dan prestasi akademik peserta didik dari proses pembelajaran yang diinformasikan pendidik sebagai tolok ukur kemajuan belajarnya (Zamsir, 2009). Tujuan penilaian akhir satuan pendidikan adalah untuk memeroleh gambaran perkembangan kompetensi peserta didik selama masa pendidikan dan digunakan sebagai dasar untuk penentuan kelulusan atau hasil belajar peserta didik. Penilaian tersebut dilakukan untuk menggambarkan perkembangan capaian kompetensi peserta didik dari tahun ke tahun sehinga diperoleh grafik perkembangan capaian komptensi secara berkala. Penilaian ini mencakup aspek akademis (pengetahuan), keterampilan, dan sikap peserta didik selama mengikuti pendidikan di satuan pendidikan. Penilaian akhir dilakukan setelah semua data atau bukti pencapaian kompetensi peserta didik 
diperoleh. Penilaian dilakukan bersama antara kepala sekolah, guru, dan komite sekolah. Penilaian akhir pada satuan pendidikan harus dilakukan secara transparan dan akuntabel sebab penilaian itu merupakan bagian yang tidak terpisahkan dengan proses pembelajaran.

Hasil penilaian menurut Nitko (2011) digunakan untuk penempatan peserta didik dalam kelompok, penempatan dalam level kursus, penugasan perbaikan, pengayaan, dan menetapkan nilai. Sejalan dengan gagasan tersebut maka dalam pelaksanaan Ujian Sekolah digunakan untuk menetapkan capaian dalam bentuk nilai. Nilai yang dicapai peserta didik dalam bentuk informasi statistik dan daya serap. Informasi statistik berupa nilai peserta didik dari hasil ujian sekolah sebagai hasil konversi skor ke skala nilai 0-10 tiap mata pelajaran. Daya serap merupakan angka capaian atau kemampuan peserta didik untuk menjawab soal dengan benar yang dinyatakan dalam persentase. Pelaporan hasil penilaian akhir satuan pendidikan ditujukan sebagai pertanggungjawaban satuan pendidikan kepada pemerintah, masyarakat, dan pihak lain yang membutuhkan. Pelaporan dilakukan untuk pemetaan kompetensi peserta didik di tingkat satuan pendidikan sehingga hasil penilaian dapat digunakan untuk membadingkan mutu atau standar pendidikan. Pemetaan berkaitan dengan standar suatu negara (NAEP, 2011) yang diperlukan untuk dapat membandingkan standar pendidikan antartahun dan juga dapat menggambarkan perkembangan capaian pendidikan suatu mata pelajaran dalam kurun waktu tertentu. Melalui pemetaan tersebut dapat dilakukan intervensi kebijakan untuk meningkatkan mutu pendidikan. Pemetaan dimaksudkan sebagai upaya untuk menentukan standar berupa informasi statistik dan daya serap soal dari pelaksanaan ujian sekolah. Upaya atau ihtiar untuk meningkatkan mutu pendidikan didasarkan pada hasil pemetaan pendidikan di SD.

Pelaksanaan ujian akhir khususnya di SD sudah ada sejak Indonesia merdeka sampai sekarang. Pada awalnya disebut Ujian Negara,
Ujian Sekolah, Evaluasi Belajar Tahap Akhir Nasional (Ebtanas), Ujian Sekolah, Ujian Akhir Sekolah Berstandar Nasional (UASBN), Ujian Nasional, dan Ujian Sekolah. Perbedaan utama dari setiap bentuk pelaksanaan ujian akhir tersebut terletak pada proses penyusunan bahan ujian, penggandaan, pelaksanaan, dan pemanfaatan hasil ujian. Bentuk Ujian Sekolah yang berlaku sekarang ini, merupakan kelanjutan dari UASBN ke ujian nasional selanjutnya menjadi ujian sekolah. Perbedaan adalah pada UASBN dan ujian nasional hanya mengujikan tiga mata pelajaran (mapel) yaitu Bahasa Indonesia, Matematika, dan IPA sedang pada Ujian Sekolah mengujikan seluruh mata pelajaran termasuk Muatan Lokal yang ada di SD. Waktu penyelenggaraan ujian sekolah dilakukan secara serentak dalam minggu yang sama sedang pada waktu UASBN dan Ujian Nasional dilakukan sebelum diujikan tiga mapel.

Pelaksanaan UASBN menurut Purwati (2009) diperlukan sebagai upaya untuk peningkatan mutu pendidikan. Purwati mendorong agar di samping pelaksanaan UASBN perlu dilakukan bentuk evaluasi (ujian) yang lain karena UASBN lebih banyak mengukur aspek pengetahuan, sedang aspek praktiknya kurang. Disarankan juga agar evaluasi (ujian) praktik hendaknya dilaksanakan di sekolah. Penilaian pencapaian kompetensi mutlak diperlukan untuk mendorong tercapainya target wajib belajar serta pencapaian pendidikan berkualitas. UASBN dan ujian praktik dilaksanakan secara terpadu sehingga pencapaian peserta didik meliputi aspek pengetahuan dan keterampilan. Peningkatan mutu pendidikan di sekolah dasar penting karena memiliki peran strategis dalam mencerdaskan kehidupan bangsa (Soedijarto, 2009). Lulusan sekolah dasar yang berkualitas akan menjadi modal dasar untuk melanjutkan pendidikan ke jenjang yang lebih tinggi. Untuk menjadikan lulusan berkualitas maka diperlukan fasilitas sebagaimana telah ditetapkan dalam standar nasional pendidikan. Adanya fasilitas tersebut akan mendorong proses pembelajaran dan pembudayaan berbagai kompetensi, nilai, 
sikap, dan keterampilan berlangsung dengan baik.

Kajian Pakpahan (2010) menyoroti mekanisme pelaksanaan UASBN yang standar, dengan menyimpulkan pelaksanaan UASBN dapat meningkatkan mutu pendidikan di sekolah dasar. Dalam kajian tersebut, penyiapan bahan ujian, penggandaan, pendistribusian, pelaksanaan ujian, yang dilakukan melalui prosedur tertentu sehingga dihasilkan bahan ujian standar. Melalui bahan ujian standar dapat diketahui nilai tiga mata pelajaran UASBN dari setiap provinsi atau kabupaten/kota. Pemetaan tersebut masih bersifat umum dan belum menguraikan pencapaian tiap sekolah dan materi pelajaran dalam ujian sekolah sehingga belum bisa langsung dijadikan sebagai acuan membandingkan capaian materi pelajaran antar satuan pendidikan. Pemetaan tersebut bermanfaat sebagai potret capaian sekolah.

Pelaksanaan ujian sekolah sebagai bentuk ujian akhir di SD dilakukan untuk mengukur pencapaian kompetensi yang ditetapkan dalam kurikulum (standar isi). Pelaksanaan tersebut didasarkan pada kenyataan bahwa pendidikan di SD dan SMP (pendidikan dasar) dilaksanakan secara terpisah dan peserta didik SD pun tidak otomatis masuk ke SMP. Ujian akhir SD hendaknya dilakukan mengikuti prosedur pelaksanaan ujian standar/baku sehingga hasil pengukurannya dapat dipercaya dan dapat dijadikan sebagai bahan pemetaan mutu pendidikan SD. Pemetaan dalam artikel ini dimaksudkan pemetaan menurut mata pelajaran dari setiap satuan pendidikan yang menguraikan tentang informasi statistik, daya serap, dan grafik tiga matpel antarsatuan pendidikan di wilayah (kabupaten/kota, provinsi, dan nasional). Berdasarkan interpretasi dari setiap unsur hasil pemetaan diperoleh informasi tentang kekurangan/kelebihan dari satuan pendidikan dan wilayah, sehingga dapat ditentukan ikhtiar untuk meningkatkan mutu pendidikan. Informasi tersebut juga digunakan sebagai dasar pengambilan suatu tindakan atau kebijakan yang dibutuhkan untuk mengatasi kekurangan/kelebihan yang dicapai oleh pemangku kepentingan seperti dinas pendidikan. Cara tersebut akan meningkatkan mutu SD dalam rangka pelaksanaan wajar dikdas. Informasi hasil pemetaan digunakan untuk meningkatkan kegiatan belajar-mengajar (Panjaitan, 2012) sehingga peserta didik tidak kuatir dengan kelulusannya.

\section{METODE}

Artikel ini merupakan hasil telaah (analisis diskriptif) dari sejumlah dokumen pelaksanaan ujian sekolah, pengalaman dalam pembimbingan/ pelatihan soal ujian sekolah di beberapa provinsi, dan hasil pemantauan pelaksanaan ujian sekolah. Analisis diskriptif dilakukan pada dokumen peraturan menteri tentang pelaksanaan ujian sekolah yang dirangkai dengan pengalaman dalam pembimbingan penulisan soal ujian sekolah. Informasi tersebut dirangkai dengan hasil pemantauan pelaksanaan ujian sekolah di Nusa Tenggara Timur, Kalimantan Timur, dan Banten, serta dokumen hasil Ujian Akhir Berstandar Nasional Tahun 2008. Penelaahan selanjutnya dilakukan pada dokumen pemetaan Ujian Sekolah dari Pusat Penilaian Pendidikan. Hasil penelaahan dari berbagai dokumen tersebut dijabarkan atau diinterpretasikan secara umum menjadi tulisan ini.

\section{HASIL DAN PEMBAHASAN Penilaian oleh pendidik}

Penilaian hasil pembelajaran dilaksanakan oleh pendidik, satuan pendidikan, dan pemerintah. Proses pembelajaran peserta didik pada satuan pendidikan diarahkan untuk mencapai tujuan pendidikan nasional sebagaimana diatur dalam standar nasional pendidikan. Penilaian dalam praktik pembelajaran di kelas (satuan pendidikan) dibedakan penilaian formatif dan sumatif (Nitko, 2011). Penilaian formatif dilakukan untuk mengetahui kemajuan belajar peserta didik serta untuk memperbaiki proses pembelajaran dalam rangka meningkatkan pencapaian kompetensi peserta didik, sedangkan penilaian sumatif dilakukan untuk mengetahui pencapaian peserta 
didik pada suatu periode waktu tertentu. Penilaian dilakukan untuk mengidentifikasi kesulitan yang mungkin dihadapi peserta didik dan menemukan cara atau strategi yang tepat untuk membantunya sehingga lebih mudah memahami kompetensi yang diajarkan. Dalam penilaian hendaknya melibatkan peserta didik untuk secara aktif berpikir mengenai proses belajar sehingga hasil pembelajaran berkembang menjadi mandiri serta penilaian diharapkan sebagai alat untuk mengukur apa yang telah dicapai. Pelaksanaan penilaian yang dilakukan oleh pendidik pada satuan pendidikan memerlukan acuan yang menjadi dasar dalam pelaksanaan penilaian peserta didik yaitu standar penilaian.

Jenis penilaian pendidik dalam standar penilaian dilakukan dalam bentuk ujian harian, ujian tengah semester; dan ujian akhir semester. Penilaian pendidik sangat bermanfaat dalam proses pembelajaran peserta didik di satuan pendidikan. Ada tiga manfaat penilaian pendidik yaitu melalui penilaian pendidik dapat menduga atau mendeteksi perkembangan pengetahuan peserta didik dan bahan tersebut digunakan sebagai pertimbangan pengembangan pembelajaran lebih lanjut. Penilaian pendidik dapat juga digunakan sebagai bahan refleksi dan mengamati perkembangan pembelajaran peserta didik untuk menentukan pencapaian pembelajaran. Pembelajaran pendidik digunakan sebagai penentuan pencapaian atau keberhasilan pembelajaran peserta didik. Para pendidik dapat memanfaatkan hasil penilaian untuk perbaikan proses pembelajaran dan penentuan pencapaian kompetensi peserta didik. Pelaksanaan ujian oleh pendidik secara terus menerus mulai dari ujian harian, ujian tengah semester, hingga ujian akhir semester akan menggambarkan mutu pendidikan di SD. Ujian yang dilakukan secara terus menerus dan diikuti dengan upaya perbaikan sesuai hasil ujian akan memperbaiki proses pembelajaran. Materi yang sukar dikuasai peserta didik akan terdeteksi segera pada saat ujian harian sehingga dapat diberikan penugasan atau remidial pada materi yang sukar tersebut. Materi atau kompetensi yang belum dikuasai peserta didik akan diukur kembali pada ujian tengah semester dan pada ujian akhir semester. Proses penilaian yang berkelanjutan tersebut akan menghasilkan pendidikan berkualitas sebagaimana diharapkan dalam pelaksanaan wajib belajar pendidikan dasar.

Penilaian yang dilakukan pendidik di satuan pendidikan menggunakan tes buatan guru dalam bentuk tes subjektif dan tes objektif (Basuki dan Hariyanto, 2014). Bentuk tes yang digunakan pendidik antara lain soal uraian, pilihan ganda, produk, dan proyek. Tes buatan guru pada dasarnya dapat dikembangkan menjadi soal baku namun jarang dilakukan karena tes disusun guru pada saat penyusunan RPP atau waktu ujian sehingga kualitas tes tersebut belum baku. Hasil pengukuran tes belum baku akan menghasilkan mutu yang beragam dan hasil penilaian tersebut sulit dipercaya oleh pihak lain yang berkepentingan dengan hasil atau mutu pendidikan. Tes atau soal yang disusun pendidik lebih banyak digunakan untuk penilaian formatif dalam rangka proses pembelajaran sehingga pendidik beranggapan soal atau tes yang digunakan tidak perlu standar yaitu tes, pengamatan, penugasan terstruktur, dan tugas mandiri (Hermawan, 2011). Dengan demikian, hasil penilaian oleh pendidik tidak dapat digunakan untuk pemetaan mutu pendidikan secara nasional. Hasil penilaian masih bersifat lokal belum dapat dijadikan sebagai gambaran mutu secara nasional. Agar hasil penilaian pendidikan dapat digunakan sebagai bahan pemetaan nasional maka diperlukan butir soal atau tes baku dan bentuk tes sama sehingga hasilnya dapat dibandingkan. Dalam pelaksanaan penilaian yang dilakukan oleh pendidik tidak menggunakan soal standar dan bentuk tes yang berbeda antarsatuan pendidikan sehingga hasilnya tidak dapat dijadikan sebagai bahan untuk pemetaan mutu pendidikan di SD dalam rangka pelaksanaan Wajar Dikdas. 


\section{Ujian Sekolah sebagai Dasar Pemetaan Sekolah Dasar \\ Pelaksanaan Ujian Sekolah}

Urgensi pelaksanaan ujian sekolah, didasarkan pada tidak ada pegangan untuk melihat hasil pendidikan melalui penilaian (ujian) terutama setelah Ebtanas dihapus dan digantikan dengan ujian sekolah. Pada masa ujian sekolah tersebut, ujian diselenggarakan secara mandiri oleh satuan pendidikan tanpa ada intervensi dari luar termasuk dinas pendidikan. Pelaksanaan ujian pada periode ini, ada yang dilaksanakan secara mandiri oleh satu sekolah atau beberapa sekolah atau yayasan bahkan ada juga yang diselenggarakan oleh dinas kabupaten/kota tertentu (Pakpahan, 2010). Proses pelaksanaan demikian kurang menguntungkan bagi pemangku kepentingan karena informasi hasil ujian atau pendidikan tidak ada dan kalaupun ada tidak dapat diperbandingkan antardaerah karena instrumen penilaian yang digunakan serta proses pelaksanaan berbeda-beda. Untuk itu, Ujian Sekolah diganti dengan UASBN hingga sekarang menjadi ujian sekolah dengan melakukan perbaikan yaitu adanya kisi-kisi nasional untuk tiga matpel dan bahan $25 \%$ soal dari Kemdikbud. Dengan perbaikan tersebut akan diperoleh data hasil ujian atau pelaksanaan pendidikan dasar.

Pada dasarnya ujian sekolah merupakan "ujian nasional" di tingkat SD, namun dalam proses penyelenggaraannya Kemdikbud hanya terkait dalam penyusunan aturan dan penyiapan naskah 25\% dari Bahasa Indonesia, Matematika, dan IPA, sedang proses-proses lainnya diserahkan kepada dinas pendidikan provinsi dan kabupaten/kota. Dasar penyelenggaraan ujian sekolah diatur dengan peraturan menteri dan disusun prosedur operasi standar pelaksanaan ujian sekolah sehingga ujian sekolah ini termasuk ujian standar dan hasilnya dapat digunakan untuk pemetaan hasil pendidikan SD. Ujian Sekolah merupakan penilaian akhir di tingkat satuan pendidikan untuk memeroleh gambaran capaian kompetensi peserta didik yang selama proses pembelajaran yang ditempuh peserta didik selama di SD. Hasil ujian sekolah digunakan untuk: 1) penentuan kelulusan peserta didik dari satuan pendidikan; 2) pertimbangan seleksi masuk satuan pendidikan berikutnya; 3 ) pemetaan mutu satuan pendidikan; dan 4) pembinaan dalam upaya untuk meningkatkan mutu pendidikan. Hasil Ujian sekolah akan digunakan dinas pendidikan kabupaten/kota sebagai alat seleksi masuk ke jenjang SMP dan bahan intervensi kebijakan dalam perbaikan mutu pendidikan. Bagi satuan pendidikan hasil ujian digunakan untuk penentuan kelulusan dan perbaikan pembelajaran. Bagi Kemdikbud hasil ujian digunakan sebagai bahan pemetaan hasil ujian (pendidikan) antarsatuan pendidikan, wilayah, dan mata pelajaran. Untuk pengorganisasian pelaksanaan Ujian sekolah maka di setiap provinsi, kabupaten/kota, dan satuan pendidikan dibentuk tim atau panitia penyelenggara ujian sekolah. Melalui ujian sekolah ini diharapkan sebagai alat akuntabel dan kredibel dalam mengukur dan sekaligus berfungsi sebagai alat pengendali serta penjamin mutu output pendidikan pada jenjang pendidikan dasar (Tola, 2007).

Penyiapan bahan ujian mengikuti pengembangan tes hasil belajar meliputi penyusunan kisi-kisi, penulisan soal, perakitan soal, pencetakan tes, dan pendistribusian tes. Penyiapan bahan ujian sekolah dilakukan berbeda antara mapel Bahasa Indonesia, Matematika, IPA, dan mapel lain. Kisi-kisi tiga mapel disiapkan oleh Kemdikbud dan kisi-kisi matpel lain disiapkan oleh satuan pendidikan dengan koordinasi dinas pendidikan kabupaten/kota. Penyusunan soal tiga mapel dilakukan oleh dinas pendidikan provinsi yang didahului dengan pelatihan penyusunan soal dari Kemdikbud. Penyusunan soal dilakukan di tingkat provinsi dengan penulis soal dari pendidik sebagai perwakilan pendidik dari kabupaten/kota yang ada di suatu provinsi. Bentuk soal yang digunakan adalah soal pilihan ganda dengan jumlah paket tiga naskah yaitu satu paket ujian utama, satu paket ujian susulan, dan satu paket ujian cadangan. Dalam rangka memeroleh soal yang baku maka dalam penulisan soal diikutsertakan para guru senior 
atau dosen perguruan tinggi dan ahli penilaian dari Kemdikbud yang bertugas untuk menelaah dan revisi soal yang dibuat oleh pendidik. Soal yang dianggap sudah baik kemudian digabungkan dengan soal linking dari Kemdikbud sebanyak $25 \%$. Soal ini dimaksudkan sebagai soal yang dapat menyetarakan soal-soal yang disusun provinsi sehingga hasil ujian sekolah dapat digunakan untuk pemetaan hasil ujian sekolah. Sementara untuk penyusunan soal matpel lain dilakukan oleh pendidik di tingkat satuan pendidikan dengan koordinasi dinas pendidikan kabupaten/kota terkait. Penyusunan soal dilakukan oleh pendidik senior di suatu kabupaten/kota. Soal-soal tersebut ditelaah dan direvisi di tingkat kabupaten/kota oleh guruguru yang berpengalaman dengan pengawasan oleh tenaga pengawas yang ada di wilayah tersebut.

Penggandaan bahan ujian tiga matpel dilakukan oleh pemda provinsi yang meliputi wilayah luas (mencakup provinsi) sehingga perlu waktu untuk pencetakan serta proses pendistribusian bahan memerlukan waktu yang lama. Pola distribusi bahan ujian tiga matpel yaitu dari percetakan yang ditunjuk provinsi ke dinas pendidikan provinsi selanjutnya ke kabupaten/kota dan tingkat kecamatan. Bahan ujian tiga matpel disimpan di kecamatan dan satuan pendidikan akan mengambil bahan ujian tersebut setiap hari sesuai jadwal pelaksanaan ujian. Sementara penggandaan bahan ujian matpel lain dilakukan oleh pemda kabupaten/ kota sehingga relatif lebih mudah dalam pencetakan dan distribusi bahan karena hanya mencakup wilayah suatu kabupaten atau kota saja. Distribusi bahan ujian matpel lain mulai dari percetakan yang ditunjuk kabupaten/kota ke dinas pendidikan kabupaten/kota selanjutnya ke kecamatan. Bahan ujian matpel lain disimpan di kecamatan dan bahan tersebut akan diambil satuan pendidikan setiap hari sesuai jadwal waktu pelaksanaan Ujian Sekolah karena jaraknya relatif dekat.

Untuk mendukung pelaksanaan Ujian Sekolah, pada umumnya satuan pendidikan melakukan persiapan melalui sosialisasi Ujian Sekolah kepada peserta didik dan orang tua serta para guru. Sosialisasi dilakukan sebagai upaya penyiapan peserta didik dalam menghadapi ujian sekolah sedang para orangtua dan pendidik diharapkan dapat mendukung pelaksanaan ujian sekolah. Upaya lain yang dilakukan untuk menghadapi ujian sekolah meliputi pendalaman materi, penambahan jam belajar, dan melakukan simulasi ujian sekolah serta melakukan pembahasan soal ujian akhir tahuntahun sebelumnya. Melalui kegiatan atau simulasi tersebut diharapkan satuan pendidikan dan peserta didik siap menghadapi pelaksanaan ujian sekolah.

Pelaksanaan ujian tiga matpel dilaksanakan satu mata pelajaran setiap hari sedang pelaksanaan mapel lain dilakukan dua mata pelajaran. Proses penyelenggaraan Ujian Sekolah mengikuti pelaksanaan ujian standar. Para petugas yang melaksanakan Ujian Sekolah diharapkan sudah mengetahui tugas dan fungsi masing-masing sehingga pelaksanaan ujian sekolah berjalan sesuai dengan prosedur operasi standar. Para peserta ujian dalam satu ruang minimal enam orang dan maksimal 20 orang dengan jumlah pengawas dua orang guru yang berasal dari satuan pendidikan yang berbeda atau pengawasan dilakukan secara silang. Sebelum pelaksanaan ujian para pengawas ruang ujian diberikan pengarahan oleh kepala sekolah tentang tugas dan kewajiban pengawas ruang dalam pelaksanaan ujian di satuan pendidikan. Sebelum ujian berlangsung para pengawas membacakan tata tertib pelaksanaan ujian sekolah.

Tugas pengawas adalah menjelaskan cara pengisian lembar jawaban, membagikan naskah ujian, memeriksa identitas peserta, dan megawasi pelaksanaan ujian di ruang ujian yang menjadi tugasnya. Pengawas ruang ujian diharapkan memeriksa informasi atau data peserta didik dalam lembar jawaban peserta didik. Naskah ujian disiapkan sesuai dengan jumlah peserta ujian sedang naskah cadangan disediakan di tingkat kecamatan. Bila ada 
naskah yang cacat dalam pencetakan atau kurang untuk setiap peserta ujian, maka naskah dapat diambil dari satuan pendidikan terdekat atau menggunakan soal cadangan yang ada di tingkat kecamatan. Dalam satu ruang ujian menggunakan satu paket, sehingga ada kemungkinan atau memudahkan peserta ujian untuk saling bekerja sama atau ada pihak lain yang ingin menyebarkan kunci jawaban. Bila satu paket akan mudah untuk melakukannya. Agar peserta ujian tidak mudah untuk melakukan kerja sama atau saling mencontek hasil ujian maka perlu dipikirkan dalam satu ruang ujian menggunakan paket soal yang lebih banyak. Bisa saja setiap peserta ujian menggunakan paket tes yang berbeda dengan peserta lain namun materi tes relatif sama. Dengan cara tersebut, hasil ujian sekolah akan semakin dipercaya sebagai hasil pengukuran komptensi peserta didik.

Dalam proses ujian berlangsung pengawas ruang ujian berkewajiban mengamati dan mengawasi serta melaporkan pelaksanaan ujian dalam berita acara pelaksanaan dan menandatangani fakta integritas yang memuat kesediaan melaksanakan ujian secara jujur, adil, dan bertanggung jawab. Proses pengepakan hasil pekerjaan peserta didik dilakukan di ruang ujian. Hal itu dilakukan untuk menghindari adanya hal-hal yang tidak diinginkan dalam proses pengepakan misalnya mengganti jawaban peserta ujian dan sebagainya. Hasil pekerjaan terutama tiga matpel peserta ujian dikumpulkan satuan pendidikan setiap hari dan diantar ke dinas pendidikan kabupaten/kota sesuai dengan wilayah satuan pendidikan yang bersangkutan.

\section{Pemetaan Hasil Ujian Sekolah}

Hasil pekerjaan peserta ujian untuk tiga matpel dikumpulkan di dinas pendidikan kabupaten/kota untuk dipindai (scan) sedang hasil pekerjaan peserta ujian mapel lain ada di tingkat satuan pendidikan penyelenggara ujian untuk dikoreksi. Hasil pemindaian tiga mapel yang dilakukan dinas kabupaten/kota dikirimkan ke provinsi untuk diskor. Untuk itu, dinas pendidikan provinsi sebelum melakukan penskoran hasil ujian, lebih dulu mendapatkan kunci jawaban soal linking dari Kemdikbud. Hasil penskoran ujian sekolah yang dilakukan dinas pendidikan provinsi dikirimkan ke dinas pendidikan kabupaten/kota selanjutnya ke satuan pendidikan di wilayahnya. Nilai dari tiga mapel dan nilai mapel lain digabungkan menjadi satu, sehingga satuan pendidikan memiliki nilai semua mata pelajaran yang diujikan.

Hasil ujian sekolah ini dimanfaatkan satuan pendidikan sebagai bahan pertimbangan untuk menentukan kelulusan peserta didik serta sebagai bahan refleksi hasil pembelajaran di satuan pendidikan yang bersangkutan. Selanjutnya hasil ujian sekolah dimanfaatkan sebagai alat seleksi masuk ke jenjang pendidikan yang lebih tinggi (SMP) yang dikoordinir oleh dinas kabupaten/kota. Hasil ujian sekolah dimanfaatkan oleh dinas pendidikan kabupaten/ kota dan provinsi sebagai bahan pertimbangan pembinaan melalui intervensi kebijakan dalam bentuk pemberian bantuan atau pemenuhan fasilitas satuan pendidikan yang dibutuhkan (sesuai). Untuk itu perlu dilakukan pengkajian atau analisis mengapa hasil Ujian Sekolah rendah atau tinggi sehingga upaya pembinaan tepat sasaran dan berdaya guna.

Hasil ujian sekolah dapat digunakan sebagai bahan pemetaan mutu pendidikan di SD karena dalam pelaksanaan ujian digunakan soal standar dan relatif sama di setiap SD. Hasil penskoran ujian sekolah yang dilakukan oleh dinas pendidikan provinsi dikirimkan ke Kemdikbud untuk digunakan sebagai bahan untuk penyetaraan hasil ujian sekolah yang ada di Indonesia. Hasil ujian dapat disetarakan (equating) walaupun peserta ujian berbeda dan bervariasi serta dalam paket tes yang digunakan terdapat soal yang sama (linking). Untuk itu perlu dilakukan pengolahan data yang berbeda secara berulang sehingga menjadi satu ukuran atau standar. Proses penyetaraan skor Ujian Sekolah lebih mudah dilakukan karena dalam ujian sekolah digunakan soal linking (yang sama, $25 \%$ ) di seluruh Indonesia. Soal dari Kemdikbud 
sudah memiliki data statistik sedang data soal yang $75 \%$ lainnya berbeda. Proses penyetaraan dilakukan dengan pengolahan data soal $25 \%$ dari Kemdikbud dengan data soal $75 \%$ dari provinsi. Hasil penyetaraan menjadikan hasil ujian sekolah terutama yang tiga mapel menjadi setara dalam satu ukuran atau standar walaupun hasilnya bervariasi antarwilayah (Herkusumo, 2011) sedangkan Rahmawati (2013) menemukan 22 dari 33 provinsi terdapat soal bersifat pencilan yaitu soal ekstrem sangat muda atau sangat sukar. Untuk itu diperlukan penyetaraan melalui soal linking dan hasil penyetaraan dapat digunakan sebagai dasar pemetaan mutu satuan pendidikan, sehingga diperoleh informasi spesifik yaitu statistik, daya serap, grafik mapel berdasarkan satuan pendidikan dan wilayah (kabupaten/kota, provinsi, dan nasional). Berdasarkan pemetaan tersebut akan diperoleh informasi kelemahan atau kekuatan satuan pendidikan berdasarkan hasil capaian tiga mapel melalui upaya membandingkan antarsatuan pendidikan di suatu wilayah. Upaya pembandingan ini akan menghasilkan informasi tentang kekurangan atau kelebihan satuan pendidikan di suatu wilayah serta informasi tersebut dikaitkan dengan kondisi atau sarana dan prasarana yang dimiliki oleh satuan pendidikan.

\section{Pemetaan SD Untuk Peningkatan Mutu SD dalam Rangka Wajib Belajar Dikdas}

Berdasarkan hasil pemetaan hasil ujian sekolah, informasi yang dapat digunakan sebagai upaya peningkatan mutu pendidikan dalam rangka Wajar Dikdas adalah informasi statistik, daya serap, dan grafik per mata pelajaran (Bahasa Indonesia, Matematika, dan IPA) menurut nasional, provinsi, kabupaten/kota, dan satuan pendidikan. Informasi yang diperoleh dari pemetaan hendaknya digunakan untuk memperbaiki proses pembelajaran sehingga satuan pendidikan tidak perlu kuatir hasil ujian sekolah yang menyebabkan peserta didiknya tidak lulus dari satuan pendidikan.
Informasi dalam statistik menguraikan tentang peringkat satuan pendidikan, nilai, dan distribusi nilai mata pelajaran. Peringkat menunjukkan kedudukan satuan pendidikan di tingkat wilayah (kabupaten/kota, provinsi, dan nasional) berdasarkan data jawaban peserta didik dalam Ujian Sekolah. Informasi statistik tersebut dijadikan acuan bagi satuan pendidikan untuk memperbaiki proses pembelajaran karena melalui proses pembelajaran yang baik tentunya akan menghasilkan lulusan yang baik. Bagi satuan pendidikan yang peringkatnya tinggi, agar posisinya tetap maka proses pembelajaran selama ini dipertahankan bahkan ditingkatkan, sedang bagi satuan pendidikan yang berada di peringkat bawah harus mengubah proses pembelajarannya. Dalam hal ini, satuan pendidikan yang rendah peringkatnya dapat belajar ke satuan pendidikan yang peringkatnya tinggi atau baik. Melalui proses ini maka hasil Ujian Sekolah dapat meningkatkan mutu pendidikan di satuan pendidikan yang bersangkutan. Bagi dinas pendidikan kabupaten/ kota atau provinsi dapat menggunakan peringkat satuan pendidikan sebagai dasar untuk menentukan sasaran intervensi kebijakan. Satuan pendidikan peringkat rendah dikaji mengapa peringkat satuan pendidikan tersebut rendah apakah karena kekurangan sarana dan prasarana pembelajaran atau kualitas tenaga pendidik rendah maka dicari kebijakan atau ihtiar yang tepat untuk meningkatkan mutu pendidikan di satuan pendidikan tersebut.

Informasi statistik memuat nilai rata-rata dan distribusi nilai mata pelajaran yang diperoleh dari capaian peserta didik dalam ujian sekolah menurut satuan pendidikan dan wilayah. Informasi statistik tersebut dapat digunakan untuk meningkatkan mutu pendidikan di SD melalui telaah nilai rata-rata dengan upaya pembandingan hasil penilaian pendidik dengan nilai ujian sekolah. Berdasarkan informasi statistik tersebut, satuan pendidikan maupun wilayah dapat melakukan pengkajian mengapa statistik nilai mata pelajaran tertentu rendah atau tinggi dan berdasarkan kajian tersebut 
satuan pendidikan dan wilayah dapat melakukan perbaikan sehingga nilai mata pelajaran tersebut meningkat di masa mendatang. Nilai statistik mata pelajaran tinggi juga perlu ditelaah apakah hasil itu sesuai dengan kondisi atau kenyataan satuan pendidikan. Bila tidak sesuai perlu dilakukan tindakan perbaikan sehingga mutu pendidikan sesuai dengan kenyataan dan hasil ujian sekolah semakin dipercaya dapat meningkatkan mutu pendidikan dalam pelaksanaan wajib belajar Dikdas.

Informasi grafik merupakan gambaran perbandingan antara nilai sekolah dengan nilai Ujian Sekolah. Informasi grafik menunjukkan bagaimana cara pendidik memberikan nilai pada mata pelajaran yang diasuhnya. Bila antara nilai sekolah dengan nilai Ujian Sekolah terdapat perbedaan yang besar maka proses pemberian nilai antara sekolah dengan Ujian Sekolah perlu dikaji. Mengapa terjadi perbedaan yang besar, apakah dalam penilaian di satuan pendidikan tidak didasarkan pada hasil pengukuran atau karena penggunaan tes yang berbeda. Berdasarkan kajian tersebut dapat dilakukan tindakan perbaikan oleh pendidik. Misalnya dari hasil pemetaan diketahui nilai hasil ujian sekolah rendah yang dapat dikaitkan dengan kekurangan buku sumber atau fasilitas belajar lainnya yang dimiliki oleh satuan pendidikan. Untuk mengatasinya diperlukan penambahan buku sumber atau fasilitas belajar lainnya.

Informasi daya serap merupakan data seberapa besar kemampuan peserta didik (ujian) dapat menjawab soal secara benar. Informasi daya serap menunjukkan persentase peserta didik dapat mengerjakan butir soal yang diujikan. Berdasarkan data hasil pemetaan, daya serap dapat dilihat menurut satuan pendidikan, wilayah kabupaten/kota, provinsi, dan nasional. Daya serap menurut satuan pendidikan dapat digunakan untuk memperbaiki proses pembelajaran karena dalam daya serap akan tampak tinggi atau rendah daya serap setiap butir soal. Satuan pendidikan melakukan pengkajian mengapa daya serap rendah; apakah karena materi sukar atau belum diajarkan atau karena salah konsep dalam pembelajaran. Untuk daya serap rendah perlu mendapat perhatian dalam proses pembelajaran sehingga materi yang rendah tersebut dapat ditingkatkan untuk masa mendatang. Upaya yang dapat dilakukan dengan menambah waktu pembahasan materi daya serap rendah atau menugaskan para peserta didik mempelajari materi tersebut secara intens. Untuk dinas pendidikan kabupaten/kota atau provinsi dapat melakukan pengkajian mengapa daya serap di wilayahnya rendah atau tinggi dan hasil kajian tersebut digunakan untuk perbaikan pendidikan di wilayahnya.

Berdasarkan uraian tersebut tampak bahwa adanya pemetaan mutu sekolah dapat digunakan sebagai sarana untuk meningkatkan mutu pendidikan. Upaya yang dilakukan terutama dengan mengkaji kekurangan atau kelebihan aspek statistik dan daya serap dari setiap satuan pendidikan maupun wilayah. Berdasarkan informasi tersebut dapat dilakukan tindakan atau intiar perbaikan sesuai dengan kondisi satuan pendidikan yang disebut dengan intervensi kebijakan. Tindakan perbaikan didasarkan pada hasil pemetaan yang meliputi peringkat nilai dan daya serap di satuan pendidikan dan wilayah. Intervensi kebijakan yang dilakukan oleh satuan pendidikan maupun dinas pendidikan akan meningkatkan mutu pendidikan secara keseluruhan. Intervensi kebijakan dilakukan sesuai dengan kondisi satuan pendidikan akan meningkatkan mutu pendidikan. Misalnya adanya perbedaan nilai dari guru dengan nilai hasil ujian sekolah. Perbedaan tersebut apakah disebabkan oleh cara pemberian nilai yang tidak standar atau sebab lain sehingga dapat diambil kebijakan yang sesuai dengan kondisi tersebut. Intervensi kebijakan secara keseluruhan sesuai dengan hasil pemetaan ujian sekolah digunakan untuk meningkatkan mutu pendidikan melalui pemenuhan kekurangan atau permasalahan yang dihadapi satuan pendidikan. Dengan pemenuhan atau penyelesaian masalah di 
satuan pendidikan akan meningkatkan mutu pendidikan sesuai dengan pelaksanaan wajar dikdas sembilan tahun.

\section{SIMPULAN DAN SARAN \\ Simpulan}

Penilaian oleh pendidik dilakukan untuk mengukur pencapaian kompetensi dan hasilnya digunakan untuk bahan perbaikan dalam proses pembelajaran. Penilaian oleh pendidik menggunakan tes yang berbeda-beda di setiap satuan pendidikan dengan kualitas yang beragam. Hasil penilaian pendidik sangat beragam sehingga tidak dapat dijadikan bahan pemetaan kualitas di Sekolah Dasar.

Pelaksanaan Ujian Sekolah di SD menggunakan soal standar dan menggunakan satu paket soal, sehingga rawan terjadi saling mencontek antar peserta ujian atau pembocoran kunci jawaban oleh pihak lain. Hasil Ujian Sekolah dapat dijadikan sebagai bahan dasar pemetaan mutu SD karena soal yang digunakan soal baku dan bentuknya relatif sama antarprovinsi serta terdapat soal linking Kemdikbud. Hasil ujian sekolah disetarakan oleh Kemdikbud sehingga hasil ujian dapat diperbandingkan. Hasil penyetaraan tersebut digunakan untuk pemetaan satuan pendidikan, yang menghasilkan peringkat, statistik, dan daya serap menurut satuan pendidikan dan wilayah (kabupaten/kota, provinsi, dan nasional).

Hasil pemetaan dijadikan sebagai bahan kajian oleh satuan pendidikan dan dinas pendidikan kabupaten/kota atau provinsi untuk mendapatkan informasi kekurangan atau kelebihan suatu sekolah. Berdasarkan kajian tersebut dapat ditentukan upaya atau ikhtiar untuk meningkatkan mutu pendidikan di satuan pendidikan melalui intervensi kebijakan oleh satuan pendidikan dan dinas pendidikan sesuai kewenangan masing-masing. Intervensi kebijakan yang sesuai dengan kondisi sekolah akan meningkatkan kualitas pendidikan di sekolah tersebut. Adanya intervensi kebijakan akan meningkatkan mutu pendidikan di SD sebagaimana diharapkan dalam pelaksanaan Wajar Dikdas.

\section{Saran}

Dari pembahasan uraian simpulan tersebut beberapa yang dapat disarankan sebagai berikut: 1) penilaian oleh pendidik menggunakan tes standar agar hasil penilaian yang dilakukan pendidik dapat dijadikan sebagai pemetaan mutu pendidikan di SD; 2) pelaksanaan Ujian Sekolah perlu dilanjutkan karena dapat berfungsi sebagai pengontrol mutu pendidikan Wajar Dikdas; 3) pengunaan jumlah paket soal dalam satu ruang hendaknya lebih dari satu paket sehingga hasil pemetaan mutu pendidikan di SD lebih berkualitas; 4) hasil pemetaan setelah pelaksanaan ujian segera dikirimkan ke satuan pendidikan dan wilayah sehingga bermanfaat bagi pendidik, satuan pendidik, dinas pendidikan untuk digunakan sebagai intervensi kebijakan dalam rangka meningkatkan kualitas pendidikan.

\section{PUSTAKA ACUAN}

Basuki, I., \& Hariyanto. 2014. Asesmen Pembelajaran. Bandung: Remaja Rosdakarya.

Cahyana, A. 2010. Upaya Peningkatan Mutu Sekolah Melalui Otonomi Satuan Pendidikan. Jurnal Pendidikan dan Kebudayaan. 16(2), hlm. 109-117.

Herkusumo, AP. 2011. Penyetaraan (Equating) Ujian Akhir Berstandar Nasional (UASBN) Dengan Teorik Klasik. Jurnal Pendidikan dan Kebudayaan. 17(4), hlm 455-471.

Hermawan, IKD., 2011. Evaluasi Program SMP Standar Nasional Berdasarkan Standar Nasional Pendidikan. Jurnal Pendidikan dan Kebudayaan. 17(6), hlm 619-635.

National Assessment of Educational Progress, 2011. Mapping State Proficiency Standards Onto the NAEP Scales:Variation and Change in State Standards forReading and Mathematics, 
2005-200. National Center for Educational Statistics U.S. Departement Education.

Nitko, A. J., \& Susan, M. B. 2011. Educational Assessment of Students (Sixth Edition). Boston, M.A: Pearson Education Inc., publishing as Allyn \& Bacon.

Pakpahan, R. 2010. UASBN Upaya Peningkatan Mutu Sekolah Dasar, Buletin Puspendik Jembatan Informasi Pusat Penilaian Pendidikan. 7(2), hlm. 19-26.

Panjaitan, M. O. 2012. Implementasi Pendekatan Belajar Aktif di Sekolah Menengah Atas. Jurnal Pendidikan dan Kebudayaan. 20(1), hlm. 44-58.

Purwati. 2009. UASBN Sebagai Upaya Peningkatan Mutu Pendidikan. Fasilitator. (2), hlm. 12-17

Pusat Bahasa, Departemen Pendidikan Nasional. 2005. Kamus Besar Bahasa Indonesia, Edisi Ketiga. Jakarta: Balai Pustaka.

Raharjo, S. B. 2014. Kontribusi Delapan Standar Nasional Pendidikan terhadap Pencapaian Prestasi Belajar. Jurnal Pendidikan dan Kebudayaan. 20(4), hlm. 470-482.

Rahmawati. 2013. Menilik Kualitas Penulisan Soal UN SD di Daerah: Studi Simulasi Pengaruh Pencilan item Parameter Tingkat Kesukaran Terhadap Estimasi Kemampuan Peserta. Value Jurnal Evaluasi \& Asesmen Pendidikan. II(01), hlm. 1-13.

Soedijarto. 2009. Kedudukan dan Peran Strategis Pendidikan Dasar Dalam Mencerdaskan Kehidupan Bangsa dan Implikasi Pembiayaannya. Fasilitator. (2), hlm. 6-11.

Somantrie, H. 2009. Peningkatan Mutu Pendidikan di Indonesia (Kebijakan, Dimensi, Proses, dan Indikator Pencapaiannya). Jurnal Pendidikan dan Kebudayaan. 15 (Edisi Khusus 1), hlm. 119.

Sudaryono, 2012. Kajian Metode Deteksi Diffrensial Item Function (DIF) Butir Soal Ujian Nasional Dengan Teori Klasik. Jurnal Pendidikan dan Kebudayaan. 18 (2), hlm. 132-144.

Tola, B., 2007. UASBN SD/MI/SDLB. Buletin Puspendik Jembatan Informasi Pusat Penilaian Pendidikan. 4(3), hlm. 3-6.

Zamsir. 2009. Penilaian Proses Pembelajaran. Buletin Puspendik Jembatan Informasi Pusat Penilaian Pendidikan. 6(3), hlm. 03-13. 
Jurnal Pendidikan dan Kebudayaan, Vol. 21, Nomor 2, Agustus 2015 